\title{
PENDIDIKAN KEAKSARAAN FUNGSIONAL DAN DAMPAKNYA TERHADAP AKTUALITAS PROFESI WARGA MASYARAKAT
}

\author{
Misran Rahman \\ e-mail: misranrahman@ymail.com \\ PLS FIP Universitas Negeri Gorontalo
}

\begin{abstract}
Abstrak: Penelitian ini bertujuan untuk mengetahui dampak pendidikan keaksaraan fungsional terhadap aktualisasi profesi anggota masyarakat di Kelurahan Kayumerah kecamatan Limboto kabupaten Gorontalo. Dengan menggunakan metode wawancara, penelitian yang dilakukan April sampai dengan Juni 2013, mengumpulkan data dengan mewawancarai 20 orang narasumber dengan latar belakang pekerjaan sebagai pedagang rokok (kecil-kecilan), pedagang sayuran, pedagang ikan, ibu rumah tangga, petani sawah, dan petani lading. Para narasumber telah mengikuti program keaksaraan fungsional. Data yang terkumpul dianalisis secara kualitatif dan disimpulkan bahwa para peserta program pendidikan keaksaraan fungsional termotivasi mengikuti program dan hasilmya berdampak positif terhadap kegiatan warga.
\end{abstract}

Kata-Kata-kata kunci: keaksaraan fungsional, dampak, aktualitas pekerjaan.

\section{FUNCTIONAL LITERACY EDUCATION AND ITS EFFECT TOWARDS PROFESSION ACTUALIZATION OF THE COMMUNITY MEMBERS}

\begin{abstract}
The purpose of this research is to describe the implementation of functional literacy education towards the professional actuality of the community members in Kayumerah village, Lomboto Subdistrict, Gorontalo District. The research conducted as from April through June 2013, collected data by interviewing 20 resource persons with various professional backgrounds. The data were analysed qualitatively and concluded that the participants of functional literacy education are motivated to complete the program and the result has significant effect to do their jobs.
\end{abstract}

Keywords: functional literacy effect, professional actuality.

\section{PENDAHULUAN}

Kelurahan Kayu Merah merupakan salah satu kelurahan di kecamatan Limboto kabupaten Gorontalo yang memiliki potensi cukup besar untuk diolah oleh masyarakat dalam rangka meningkatkan kehidupan. Potensi utama dari kelurahan tersebut adalah areal pertanian yang terhampar luas baik area persawahan, perkebunan, maupun area ladang. Selain itu terdapat pula potensi hutan dan lahan tambak yang cukup menjanjikan serta memberi manfaat bagi warga kelurahan kayu merah dan sekitarnya.

Air yang mengalir di kelurahan Kayu Merah bersumber dari pengairan di Bendungan Bionga yang debet airnya cukup besar meskipun bukan musim penghujan. Hal ini merupakan suatu keuntungan bagi petani sawah di kelurahan tersebut jika dibandingkan dengan sawah di kelurahan lain yang hanya merupakan sawah tadah hujan. Oleh karena itu, potensi-potensi ini membutuhkan sumber daya manusia yang memiliki kualitas memadai untuk mengolahnya. Tanpa adanya kualitas sumber daya manusia yang potensial maka sumber daya alam tersebut tidak terolahkan secara optimal.

Berdasarkan sumber yang diperoleh dari kelurahan Kayu Merah, jenis pekerjaan yang digeluti warga masyarakat, cukup bervariasi. Sebagian warga masyarakat bekerja pegawai negeri sipil, pegawai swasta, wiraswasta (wirausaha), pedagang, nelayan, petani, dokter, tukang, dan beberapa jenis pekerjaan lain. Namun demikian masih terdapat warga masyarakat miskin dan pengangguran. Selanjutnya untuk tingkat pendidikan, memiliki tingkat pendidikan sebagai berikut; Doktor, Magister, Sarjana, Diploma, SMA sederajat, SMP sederajat, SD sederajat, bahkan sebagian warga masyarakat yang masih buta huruf.

Khusus untuk warga masyarakat buta huruf, di kelurahan Kayu Merah sampai dengan tahun 2013 masih berjumlah sebanyak 417 orang. Jumlah ini masih cukup tinggi sebanyak $16,74 \%$ dibandingkan dengan jumlah penduduk kelurahan Kayu Merah sebanyak 2491 jiwa. Oleh adanya jumlah tersebut maka perlu 
dilakukan pembelajaran terhadap warga masyarakat buta huruf melalui program keaksaraan fugsional.

Program keaksaraan fungsional telah dilakukan di kabupaten Gorontalo termasuk kelurahan Kayu Merah kecamatan Limboto. Fenomena yang diperoleh dari hasil survei terbatas, dimana sebagian masyarakat mengatakan bahwa program tersebut telah bermanfaat untuk menunjang pekerjaannya namun sebagian lain mengatakan program tersebut belum memberikan manfaat yang berarti bagi pekerjaan. Berdasarkan fenomena ini, maka peneliti melakukan studi tentang dampak dari program keaksaraan fungsional terhadap aktualitas pekerjaan masyarakat.
Dalam tahap pembelajaran, kegiatan belajar pembelajaran pada program keaksaraan fungsional terdiri dari lima langkah kegiatan yaitu calistungdasi (membaca, menulis, berhitung, diskusi dan aksi). Langkah-langkah kegiatan tersebut bukan berarti langkah yang harus berurutan, tetapi bisa saja dilakukan secara acak. Untuk tahap evaluasi pembelajaran dimana acuan evaluasi pembelajaran diharapkan dapat dipelajari dan diterapkan oleh semua pihak, Evaluasi pembelajaran program keaksaraan fungsional memiliki tiga tahapan penilaian, yaitu penilaian sebelum, penilaian proses, dan penilaian setelah pembelajaran.

\section{METODE PENELITIAN}

Subjek dalam penelitian ini adalah warga masyarakat kelurahan Kayu Merah kecamatan Limboto kabupaten Gorontalo yang telah mengikuti program keaksaraan fungsional. Jumlah warga yang dijadikan subjek penelitian sebanyak 15 orang dengan aktivitas pekerjaan, terdiri atas pedagang rokok sebanyak 3 orang, pedagang sayur sebanyak 3 orang, tukang sebanyak 2 orang, ibu rumah tangga sebanyak 3 orang, dan petani sebanyak 4 orang. Penelitian ini dilaksanakan dari bulan April sampai dengan Juni 2013.

Selanjutnya metode yang digunakan dalam penelitian ini adalah deskriptif kualitatif. Dalam pengumpulan data penelitian, penulis menggunakan metode wawancara yang dituntun oleh pedoman wawancara. Kegiatan wawancara dilaksanakan dengan cara mendatangi rumah-rumah warga masyarakat sebagai subjek penelitian. Selain wawancara dengan warga belajar, peneliti juga melakukan wawancara dengan penyelenggara program keaksaraan dan tutor. Informasi yang diperoleh dari penyelenggara sehubungan dengan manajemen penyelenggaraan keaksaraan fungsional, sedangkan informasi yang diperoleh dari tutor berkaitan dengan pembelajaran dalam keaksaraan fungsional.

Analisis data yang dilakukan menggunakan analisis kualitatif dengan mendeskripsikan hasil fenomena yang diperoleh pada proses penelitian dan hasil wawancara.

\section{HASIL DAN PEMBAHASAN}

Berdasarkan hasil wawancara, diperoleh kesan bahwa responden sebagian besar termotivasi untuk mengikuti program keaksaraan fungsional meskipun ada sebagian yang kurang bahkan tidak ada motivasi dalam mengikuti program keaksaran. Bagi yang termotivasi, rata-rata menyadari bahwa keaksaraan fungsional dibutuhkan, sementara yang tidak termotivasi, sebagian mengatakan tidak mengetahui dengan pasti untuk apa program keaksaraan tersebut diikuti.

Tentang perasaan informan dalam mengikuti program keaksaraan, sebagian besar menyatakan senang, sementara sebagian yang lain menyatakan kurang senang. Responden yang menyatakan senang, pada umumnya telah merasakan manfaat dari program keaksaraan tersebut, misalnya sudah bisa membaca koran sehingga dapat memperoleh informasi yang bermanfaat. Demikian pula sebagian dari mereka yang menyatakan senang oleh karena sudah bisa membaca short message service (sms). Informan yang mengatakan kurang senang dengan program keaksaraan oleh karena program tersebut mengganggu aktivitas mereka dalam bekerja.

Tentang kebermanfaatan program keaksaraan fungsional, setelah diidentifikasi sebagian menyatakan bahwa program keaksaraan bermanfaat termasuk membantu dalam pekerjaan mereka. Oleh karena itu meskipun ada kendala dalam mengikuti keaksaraan fungsional, mereka tetap berupaya untuk mengikuti dengan baik program keaksaraan tersebut. Sehubungan dengan kebermanfaatan dimaksud lebih lanjut ditanyakan kepada responden untuk dukungan program keaksaraan terhadap aktualitas pekerjaan masing-masing responden, dengan membagi kategori menjadi: (1) sangat mendukung, (2) mendukung, (3) kurang mendukung, dan (4) tidak mendukung 
diperoleh deskripsi hasil wawancara sebagaimana pada tabel 1.

Tabel 1. Deskripsi Pendapat Warga Belajar Tentang Program KF yang Telah Diikuti

\begin{tabular}{|l|c|c|c|c|c|}
\hline \multirow{2}{*}{ Jenis pekerjaan } & \multicolumn{4}{|c|}{ Deskripsi pendapat } & \multirow{2}{*}{ Jumlah } \\
\cline { 2 - 6 } & 1 & 2 & 3 & 4 & \\
\hline Pedagang rokok & - & 1 & 2 & - & 3 \\
\hline Pedagan Sayur & - & 1 & 2 & - & 3 \\
\hline Tukang & - & - & 1 & 1 & 2 \\
\hline Ibu rumah tangga & - & 1 & 2 & - & 3 \\
\hline Petani & - & 1 & 2 & 1 & 4 \\
\hline Total & & 4 & 9 & 2 & 15 \\
\hline
\end{tabular}

Keterangan:

1 = tidak mendukung $3=$ mendukung

$2=$ kurang mendukung $4=$ sangat mendukung

Dari tabel 1 nampak bahwa dari 3 responden pedagang rokok, 2 orang mengemukakan bahwa keaksaraan fungsional mendukung dalam pekerjaan menjual rokok, namun demikian 1 orang pedagang rokok menyatakan kurang mendukung aktivitas profesinya. Selanjutnya untuk pedagang sayur, dari 3 responden yang diwawancarai, 2 orang mengemukakan bahwa keaksaraan fungsional mendukung dalam pekerjaan menjual sayur dan 1 orang menyatakan kurang mendukung. Untuk tukang, dari 2 responden yang diwawancarai, 1 orang mengemukakan bahwa keaksaraan fungsional mendukung dalam pekerjaan menjual sayur serta 1 orang menyatakan sangat mendukung. Untuk Ibu rumah tangga, dari 3 responden yang diwawancarai, 1 orang mengemukakan bahwa keaksaraan fungsional kurang mendukung dalam pekerjaan mengelola rumah tangga dan 2 orang menyatakan mendukung aktivitas profesinya. Terakhir untuk petani, dari 4 responden yang diwawancarai, 2 orang mengemukakan bahwa keaksaraan fungsional mendukung dalam pekerjaan bertani, bahkan 1 orang menyatakan sangat mendukung. Namun demikian, ada 1 orang yang menyatakan tidak mendukung.

Secara umum hasil analisis dari tabel 1 terlihat bahwa dari 15 orang yang diwawancarai, hanya 4 orang responden yang menyatakan bahwa program keaksaraan fungsional kurang mendukung aktivitas profesi mereka, selanjutnya sebanyak 9 orang responden mengemukakan bahwa program keaksaraan mendukung aktualitas pekerjaan, dan 2 orang responden menyatakan sangat mendukung. Berdasarkan hasil analisis tersebut nampak bahwa sebagian besar responden menyatakan bahwa program keaksaraan fungsional mendukung aktivitas profesi.

Untuk kegiatan pembelajaran menurut para responden bahwa fasilitator lebih banyak menggunakan metode diskusi, di samping metode ceramah, tanya jawab, dan brainstorming. Melalui metode diskusi warga belajar lebih mudah untuk saling berinteraksi serta mudah memahami materi yang disampaikan tutor. Selanjutnya menurut hasil pengamatan beberapa responden terhadap tutor, penjelasan tutor tentang konsep pemecahan masalah terkesan minim. Sebagian warga belajar masih membutuhkan penjelasan lanjutan jika diberi tugas. Tutor berusaha membimbing dan menjawab pertanyaan yang diajukan warga belajar.

\section{Pembahasan}

Di kelurahan Kayu Merah Kecamatan Limboto program keaksaraan fungsional telah dilaksanakan secara baik dalam beberapa angkatan. Program tersebut dilaksanakan sesuai tahapan-tahapan umum kegiatan keaksaraan fungsional, yaitu tahap identifikasi diawali dengan melakukan identifikasi baik berupa minat maupun kebutuhan kehidupannya sehari-hari. Hal ini dimaksudkan agar tutor dapat mengetahui apa yang benar-benar dibutuhkan oleh warga belajar mulai dari warga belajar itu sendiri sampai terhadap lingkungan sekitarnya. Selanjutnya tahap perencanaan pembelajaran KF, yaitu suatu kegiatan yang akan dilakukan untuk mempersiapkan pembelajaran keaksaraan fungsional agar lebih efektif dan efisien. Penyusunan suatu program hendaknya didasari pada data-data yang akurat untuk memperoleh pilihan alternatif yang paling tepat. Secara harfiah perencanaan diartikan sebagai penentuan urutan tindakan, perkiraan biaya serta penggunaan waktu untuk suatu kegiatan yang berdasarkan atas data-data, dengan memperhatikan prioritas yang wajar dan efisien untuk tercapainya tujuan.

Sebagaimana hasil wawancara secara umum peserta menyatakan senang dengan program keaksaraan fungsional yang dilakukan. Strategi yang diberlakukan pada keaksaraan fungsional, berbeda dengan strategi yang diberlakukan pada anak didik pada pendidikan formal maupun Paket $A$. Sebagaimana telah dikemukakan bahwa pendidikan keaksaraan fungsional terdiri dari dua konsep yaitu "keaksaraan" dan "fungsional". Keaksaraan (literacy) secara sederhana diartikan sebagai "kemampuan untuk membaca dan menulis". Keaksaraan didefinisikan secara luas sebagai pengetahuan dasar dan keterampilan yang diperlukan oleh semua warga negara dan salah satu fondasi bagi penguasaan 
kecakapan-kecakapan hidup yang lain. Istilah fungsional dalam keaksaraan, berkaitan erat dengan fungsi dan/atau tujuan dilakukannya pembelajaran di dalam program pendidikan keaksaraan, serta adanya jaminan bahwa hasil belajarnya benarbenar "bermakna/bermanfaat" atau fungsional bagi "peningkatan mutu dan taraf hidup" warga belajar dan masyarakatnya.

Selanjutnya sebagian dari mereka menyatakan bahwa dalam mengikuti keaksaraan fungsional meskipun ada kendala namun tetap dapat belajar dengan baik. Demikian pula dengan penilaian terhadap tutor, penggunaan metode, strategi, dan teknik nampaknya cukup baik, dan menyebabkan warga belajar mudah berinteraksi serta mudah memahami materi yang disampaikan tutor. Terakhir tutor berusaha membimbing dan menjawab pertanyaan yang diajukan warga belajar.

Analisis data kualitatif untuk semua profesi responden pada umumnya berpendapat bahwa keaksaraan fungsional mendukung aktivitas profesi mereka. Bagi pedagang rokok manfaat keaksaraan fungsional sangat dirasakan dalam transaksi dan penjualan, terutama kemampuan dalam tukar menukar uang. Demikian pula program tersebut bermanfaat bagi responden dalam membaca pesan pada iklan serta memaknai iklan larangan merokok. Dengan adanya program ini sebagian responden penjual rokok ternyata baru mengetahui adanya bahaya rokok bagi kesehatan.

Bagi pedagang sayur, dari dua informan yang mengemukakan bahwa keaksaraan fungsional mendukung aktivitasnya dalam pekerjaan mereka menjual sayur terutama dalam masalah tukar menukar uang. Selain itu, di antara responden sudah mulai berupaya membaca koran dan mencari manfaat sayuran bagi kesehatan.

Untuk Ibu rumah tangga, manfaat program keaksaraan fungsional, materi berhitung bermanfaat untuk menghitung tentang uang dan ukuran-ukuran untuk kebutuhan rumah tangga. Selanjutnya kemampuan membaca digunakan dalam membaca majalah, koran, buletin baik yang sifatnya umum maupun berhubungan dengan kewanitaan serta rumah tangga termasuk menu masakan dan sebagainya.

Untuk tukang, program keaksaraan membantu dalam menghitung, pengukuran, campuran-campuran, kemiringan dan sebagainya yang berhubungan dengan perumahan, beton, dan kayu. Selain itu membantu tukang dalam membaca majalah serta koleksi bentuk dan model rumah.

Terakhir untuk para petani program keaksaraan fungsional menurut mereka sangat membantu dalam mengakses informasi dari buletin dan brosur pertanian menyangkut pembibitan, penanaman, penyiangan, pemberian pupuk dan obat anti hama, serta panen. Demikian pula dalam hitung menghitung sehubungan dengan pertanian.

\section{PENUTUP}

\section{Kesimpulan}

Program keaksaraan fungsional telah dilaksanakan di kelurahan Kayu Merah kabupaten Gorontalo untuk warga yang masih tergolong buta huruf. Hasil program keaksaraan fungsional memberikan motivasi kepada sebagian besar warga untuk dapat melek huruf karena mendukung pekerjaan. Namun, ada juga sebagian warga yang kurang termotivasi bahkan tidak ada motivasi dalam mengikuti program keaksaran karena program keaksaraan fungsional dianggap mengganggu aktivitas dalam bekerja. Bagi warga yang merasakan manfaat dari program keaksaraan fungsional, terbantu dalam hal transaksi penjualan dan pembelian, membaca, menulis, dan berhitung. Disarankan agar program ini memperoleh dukungan dari berbagai pihak.

\section{DAFTAR PUSTAKA}

Aminullah. (2007). Akan berhasilkah pemberantasan buta huruf di Indonesia? BPPLSP Regional V Bandung

Brigham, F. E. dan F. J. Westen. (1990). Dasarmanajemen keuangan (alih bahasa: A. Sirait). Jakarta: Erlangga

Depdiknas. (2006). Standar kompetensi keaksaraan. Jakarta. Direktorat Pendidikan Masyarakat.

Djalal, F. \& Sardjunani, N. (2006). Peningkatan keak- saraan yang lebih baik untuk Indonesia. http:// harian-blobal.com/new,php?item. 25325.10 (diakses 12 September 2012)

Djalal, F., et.al. (2005). Pendidikan keaksaraan, filosofi, strategi, dan implementasi. Jakarta. Ditjen PLS.

Hardika. (2010). Model fasilitasi pembelajaran untuk peningkatan kreativitas belajar. Disertasi. UPI Bandung

Kusnaidi, dkk. (2003). Keaksaraan fungsional di Indo- 
nesia. Jakarta: Mustika Aksara

Rahman, M. (2011). Pengembangan model on the job training berbasis andragogi untuk peningkatan kompetensi pendidik anak usia dini. Jakarta:
Jurnal IImiah VISI

Sudjana, D. (2005). Strategi pembelajaran dalam pendidikan luar sekolah. Bandung: Nusantara Press 